\title{
A Tumor Microenvironment-Directed Multisensitive Nanorobotics for Synergistic Photothermal Therapy/Chemotherapy
}

Yang Zhang ${ }^{a, *}$, Lu Yang ${ }^{a}$, Wen-tong Li $i^{b}$, Cheng-cheng Gai ${ }^{b}$, Bo Huc ${ }^{c}$, Ai-hua Liu ${ }^{a, d, *}$

E-mail address: zhangyang@qdu.edu.cn(Y. Zhang), liuah@qdu.edu.cn (A.H. Liu)

${ }^{a}$ Institute for Chemical Biology \& Biosensing, College of Life Sciences, Qingdao University,

Qingdao 266071, China. ${ }^{b}$ Department of pathology, School of Clinical Medicine, Weifang

Medical University, Weifang 261053, China. ${ }^{c}$ Department of Biochemistry and Molecular

Biology, School of Life Science, China Medical University, Shenyang 110122, China. ${ }^{d}$ School of

Pharmacy, Medical College, Qingdao University, 308 Ningxia Road, Qingdao 266071, China. 


\section{EXPERIMENTAL SECTION}

1.1 Chemicals and materials. Copper chloride $\left(\mathrm{CuCl}_{2} \cdot 2 \mathrm{H}_{2} \mathrm{O}\right)$, ammonium sulfide solution $\left(\mathrm{NH}_{4} \mathrm{~S}, 20 \mathrm{wt} \%\right)$, polyvinylpyrrolidone (PVP-K30), mercaptosuccinic acid, 1-(3-dimethylaminopropyl) -3-ethylcarbodiimide hydrochloride (EDC), N-hydroxysuccinimide (NHS), sodium hydroxide $(\mathrm{NaOH})$, sodium borohydride $\left(\mathrm{NaBH}_{4}\right)$ were purchased from Aladdin industrial corporation. 2-propanol, phosphate, hydrazine anhydrous solution $\left(\mathrm{N}_{2} \mathrm{H}_{4} \cdot \mathrm{H}_{2} \mathrm{O}\right)$ and absolute ethylalcohol $\left(\mathrm{C}_{2} \mathrm{H}_{6} \mathrm{O}\right)$ were purchased from Shanghai Regent Co. Ltd. Hydrogen tetrachloroaurate (III) $\left(\mathrm{HAuCl}_{4} \cdot 3 \mathrm{H}_{2} \mathrm{O}\right), 4$ ', 6-diamidino-2-phenylindole (DAPI) and doxorubicin (DOX), 3-[4,5-dimethylthiazol-2-yl]-2,5-diphenyltetrazoliu m bromide (MTT), and cystamine dihydrochloride $\left(\mathrm{C}_{4} \mathrm{H}_{12} \mathrm{~N}_{2} \mathrm{~S}_{2} \cdot 2 \mathrm{HCl}\right)$ were purchased from Sigma-Aldrich (St. Louis, USA). Dulbecco's modified Eagle's medium/High Glucose (DMEM/High Glucose), $0.25 \%$ trypsin- EDTA, penicillin/streptomycin and fetal bovine serum are obtained from Thermo Scientific (Logan, Utah, USA). These reagents are at least of analyticalreagent grade and used as received without further treatment.

1.2 Characterization. The scanning electron microscope (SEM) images were obtained from EVO18 instrument and Transmission electron microscope (TEM) were using FEI Tecnai G2 S-Twin transmission electron microscope with acceleration voltage of $200 \mathrm{kV}$ to measure the morphology. The X-ray diffraction (XRD) measurements were conducted on a DX2700 Focus diffractometer (China) with $\mathrm{Cu}$ $\mathrm{K} \alpha$ radiation $(\mathrm{I}=1.5418 \AA$ ). X-ray photoelectron spectroscopy (XPS) was performed by SCALab250 electron spectrometer (Thermo Scientific Corporation) with 
monochromatic $150 \mathrm{~W} \mathrm{Al} \mathrm{K \alpha}$ radiation. Raman spectra were determined through raman spectrometer (RAM HR) that used the $486 \mathrm{~nm}$ line of an Ar ion laser. Nitrogen absorption/desorption analysis was measured using a Micromeritics ASAP 2020 M apparatus. The UV-visible absorption spectrum (UV-Vis) datas were obtained from Hitachi U-2910. The average size and zeta potential were determined by dynamic light scattering (DLS) using a ZetaSizer Nano ZS90 (Malvern, UK).

1.3 Synthesis of hCuS and hCu2-xS@Au nanoparticles. 1000 mg of PVP-K30 was dissolvcddsewqyed in $300 \mathrm{~mL}$ 2-propanol, after added the $85.25 \mathrm{mg}$ $\mathrm{CuSO}_{4} \cdot 2 \mathrm{H}_{2} \mathrm{O}$ and $200 \mathrm{mg}$ of $\mathrm{NaOH}$, stirred until completely dissolved at the room temperature. $1400 \mu \mathrm{L}$ of $\mathrm{N}_{2} \mathrm{H}_{4} \cdot \mathrm{H}_{2} \mathrm{O}$ was cautiously added, dropwise, while strring for $10 \mathrm{~min}$. The obtained product was gathered by centrifuged and washed three times with deionized water. Followed redispersible into the deionized water, the next addition of $175 \mu \mathrm{L}\left(\mathrm{NH}_{4}\right)_{2} \mathrm{~S}$ solution, strring for another $2 \mathrm{~h}$. Finally, the hollow copper sulfide nanoparticles were collected by centrifugation (12000 rpm, 10min) and water scrubbing.

$20 \mathrm{mg} \mathrm{hCuS}$ was dispersed in absolute ethanol, $1000 \mathrm{mg}$ PVP-K30 which as the end-blocking agent was added, strring until entire dissolution. The following addition was $30 \mathrm{~mL}$ of $\mathrm{HAuCl}_{4}(0.5 \mathrm{mM})$, which needed protect it from light and reacted for $20 \mathrm{~min}$. Then, $0.5 \mathrm{~mL} \mathrm{NaBH}_{4}(3 \mathrm{mM})$ was added and the mixture was stirred for another $30 \mathrm{~min}$ and the gold nanoparticles were wrapped on the surface of hollow copper sulfide. The products were collected by centrifugation at $12000 \mathrm{rpm}$ for 15 min and washed three times with ethanol and deionized water, respectively. 
1.4 Synthesis of ss-hCu2-xS@ Au. 1 mg hCu $\mathrm{hu}_{2-\mathrm{x}} \mathrm{S} @ \mathrm{Au}$ was dispersed in $2 \mathrm{~mL}$ anhydrous ethanol, and $12.5 \mathrm{mg}$ mercaptosuccinic acid was added and the mixture was stirred at room temperature for $24 \mathrm{~h}$. Afterwards, the obtained product $\mathrm{hCu}_{2-\mathrm{x}} \mathrm{S} @ \mathrm{Au}-\mathrm{COOH}$ was centrifuged at $12000 \mathrm{rpm}$ for $10 \mathrm{~min}$ and washed with deionized water. $50 \mathrm{mg} \mathrm{hCu} \mathrm{u}_{2 \mathrm{x}} \mathrm{S} @ \mathrm{Au}-\mathrm{COOH}$ was dispersed in phosphate buffer solution (PBS) (pH 5.5, $10 \mathrm{mM}$ ), and the carboxyl was activated for 20 min by adding $10 \mathrm{mg}$ EDC and 10mg NHS, simultaneously. Afterwards, with the addition of $100 \mathrm{mg}$ cystamine dihydrochloride, the $\mathrm{pH}$ of the mixed solution was adjusted to 7.5 by using the $\mathrm{NaOH}$ solution $\left(1 \mathrm{~mol} \mathrm{~L}^{-1}\right)$ under vigorous stirring for $3 \mathrm{~h}$ at room temperature. The final product was centrifuged and washed by deionized water, which noted ss-hCu ${ }_{2-\mathrm{x}} \mathrm{S} @ \mathrm{Au}$ for future use.

1.5 DOX loading and guard assembling. DOX is employed as model drug molecule to investigate the loading and controlled release capability of the drug

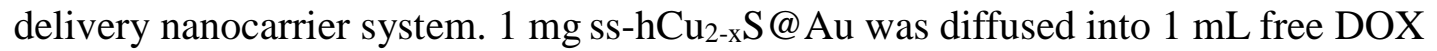
solution (400 $\left.\mathrm{mg} \mathrm{L}^{-1}\right)$ in PBS buffer $\left(10 \mathrm{mM}\right.$, pH 7.4) under stirring in dark at $37^{\circ} \mathrm{C}$ for $6 \mathrm{~h}$. The mixture was centrifuged and washed twice with PBS to wash off the loosely retained DOX and obtain the DOX-loaded ss-hCu $\mathrm{Cu}_{2-\mathrm{x}} \mathrm{S} @ \mathrm{Au}$, named $\mathrm{hCu}_{2-\mathrm{x}} \mathrm{S} @ \mathrm{Au}-\mathrm{DOX}$. Afterwards, the hCu $\mathrm{u}_{2-\mathrm{x}} \mathrm{S} @ \mathrm{Au}-\mathrm{DOX}$ sediment was suspended in 1 $\mathrm{mL}$ 1-tetradecanol $(0.5 \mathrm{mM})$ and shocked for $1 \mathrm{~h}$, the final nanocomposite with guard of $\mathrm{hCu}_{2-\mathrm{x}} \mathrm{S} @ \mathrm{Au}-\mathrm{DOX}-\mathrm{TDA}$ was obtained by centrifuging and washing. The quantitative analysis of the DOX was managed by UV-vis spectrophotometry at 482 $\mathrm{nm}$. The loading factor of DOX was calculated by the following equation [1], 


$$
\text { Loadingfactor } \%=\frac{m_{D O X}-m_{u D O X}}{m_{D O X}} \times 100 \%
$$

where $m_{D O X}$ represents the total mass of DOX, $m_{u D O X}$ is the quality of deprived DOX.

1.6 Condition-Induced Release of Cargos in Vitro. To investigate $\mathrm{pH}$-induced the DOX released properties of $\mathrm{hCu}_{2-\mathrm{x}} \mathrm{S} @ \mathrm{Au}-\mathrm{DOX}-\mathrm{TDA}$, which the nanovechiles was treated with $2 \mathrm{~mL}$ PBS with different pHs $(5.5,7.4,8.5)$ and vibrated in thermostatic oscillator at $37^{\circ} \mathrm{C}$. After different incubation time intervals (1, 2, 4, 8, 12, 24, 36, $\left.48 \mathrm{~h}\right)$, the solution was centrifuged at $12000 \mathrm{rpm}$ for $2 \mathrm{~min}$ to precipitate the residual DOX-loaded nanovechiles. $500 \mu \mathrm{L}$ supernatant was removed for measuring the amount of released DOX, and then the same volume of fresh buffer was added into the residual solution. The cumulative release of DOX was calculated as a percentage with respect to the loaded DOX within the delivery system.

To investigate external temperature-induced the DOX released properties of hCu $u_{2-x} \mathrm{~S} @ A u-D O X-T D A$, which hCu $\mathrm{h}_{2-\mathrm{x}} \mathrm{S} @ \mathrm{Au}-\mathrm{DOX}-\mathrm{TDA}$ was suspended in PBS (pH $5.5,7.4,8.5)$ and managed at the temperature of $37,47,57{ }^{\circ} \mathrm{C}$, respectively. $500 \mu \mathrm{L}$ supernatant was removed for measuring the amount of released DOX, and then the equal volume of fresh buffer was added into the residual solution. The photo-responsive release was investigated by irradiating at the $808 \mathrm{~nm}$ laser for 10 min with the power density at $1.5 \mathrm{~W} \mathrm{~cm}^{-2}$ at room temperature with gentle shaking and then was shaken gently at $37{ }^{\circ} \mathrm{C}$ for predetermined time intervals, without irradiating was used as control.

Glutathione-induced the release was also evaluated by incubating $\mathrm{hCu}_{2-\mathrm{x}} \mathrm{S} @ \mathrm{Au}-\mathrm{DOX}-\mathrm{TDA}\left(1 \mathrm{mg} \mathrm{mL}^{-1}\right)$ with various concentration of glutathione $(0$, 
$0.5,1,2.5,5,10,20 \mathrm{mM}$ ) and vibrating $37^{\circ} \mathrm{C}$, then centrifuged and fetched $500 \mu \mathrm{L}$ supernate at each time point $(2,4,8,12,24,36,48 \mathrm{~h})$. UV-vis absorption spectrum was used to carry quantitative analysis. The mentioned condition-induced release behavior of the DOX loaded $\mathrm{hCu}_{2-\mathrm{x}} \mathrm{S} @ \mathrm{Au}$ without TDA plugging the entrance was taken as control. The accordant loading and releasing processes with above description were conducted.

1.7 Photothermal effect and stability. To measure the photothermal behavior of $\mathrm{hCuS}$ and $\mathrm{hCu}_{2-\mathrm{x}} \mathrm{S} @ \mathrm{Au}$, the nanoparticles were dispersed in PBS (10 mM, pH 7.4) with different concentrations $\left(300,500,1000 \mathrm{mg} \mathrm{L}^{-1}\right)$ and irradiated by $808 \mathrm{~nm}$ laser with diverse power densities $\left(1.5 \mathrm{~W} \mathrm{~cm}^{-2}, 2.5 \mathrm{~W} \mathrm{~cm}^{-2}, 3.5 \mathrm{~W} \mathrm{~cm}^{-2}\right)$ for $20 \mathrm{~min}$, the distance between the liquid level and the laser head was $5.0 \mathrm{~cm}$ ), and the temperature changes were recorded at inveral exposure time (0-1200 s). Pre- and post-illumination temperatures were managed by an infrared thermal imaging camera. Besides, photothermal stability of the nanomaterial was examined, hCuS and $\mathrm{hCu}_{2-\mathrm{x}} \mathrm{S} @ \mathrm{Au}$ (500 $\mu \mathrm{g} \mathrm{mL}^{-1}$ ) was experienced continuously heating and cooling for five times.

\section{Calculation of photothermal conversion efficiency:}

To evaluate the photothermal conversion efficiency, $\mathrm{hCu}_{2-\mathrm{x}} \mathrm{S} @ \mathrm{Au}(1 \mathrm{~mL}, 500 \mu \mathrm{g}$ $\left.\mathrm{mL}^{-1}\right)$ was located centrifuge tubes under the $808 \mathrm{~nm}$ NIR laser $\left(1.5 \mathrm{~W} \mathrm{~cm}^{-2}\right)$, the temperature was recorded until reached a steady-state temperature. The photothermal conversion efficiency $(\eta)$ was calculated by using the following Equation (2)-(5) according to the previous reported by Roper [2, 3].

$$
\eta=\frac{h S\left(T_{\max }-T_{\text {surr }}\right)-Q_{\text {dis }}}{I\left(1-10^{-A_{808}}\right)}
$$




$$
h S=\frac{m_{D} C_{D}}{\tau_{S}}
$$

For the equation (2): $\mathrm{A}_{808}$ was the absorbance of the $\mathrm{hCu}_{2-\mathrm{x}} \mathrm{S} @ \mathrm{Au}$ at $808 \mathrm{~nm}\left(\mathrm{~A}_{808}\right.$ $=1.052$ ). where $h$ represented the heat transfer coefficient, $S$ was the surface area of the container, $T_{\max }$ was the equilibrium temperature, $T_{\text {surr }}$ was temperature of the surroundings, $Q_{\text {dis }}$ expressed the heat dissipation by the solvent, $I$ was laser power $\left(1.5 \mathrm{~W} \mathrm{~cm} \mathrm{~cm}^{-2}\right)$, and was measured using a quartz cuvette cell containing pure water without the nanoparticles; For the equation 3: where $\tau_{\mathrm{s}}$ was the sample system time constant, $m_{\mathrm{D}}$ and $C_{\mathrm{D}}$ were the mass $(1.0 \mathrm{~g})$ and heat capacity $\left(4.2 \mathrm{~J} \mathrm{~g}^{-2}\right)$ of deionized water used as the solvent, respectively.

1.8 Cell experiments. Human cervical cancer cell line (HeLa cells) is used to assess the cytotoxicity. HeLa cells were cultivated in high-glucose DMEM containing $10 \%$ fetal bovine serum, $1 \%$ penicillin/streptomycin in $5 \% \mathrm{CO}_{2}$ at $37{ }^{\circ} \mathrm{C}$, and the standard MTT cell assay was operated. HeLa cells were incubated in 96-well plates and cultured for $24 \mathrm{~h}$ and washed with PBS, and the medium was changed to fresh DMEM medium containing the indicated concentrations of DOX, $\mathrm{hCu}_{2-\mathrm{x}} \mathrm{S} @ \mathrm{Au}-\mathrm{TDA}$ and $\mathrm{hCu}_{2-\mathrm{x}} \mathrm{S} @ \mathrm{Au}-\mathrm{DOX}-\mathrm{TDA}$, respectively, and incubated for $20 \mathrm{~h}$. Afterwards, 20 mL MTT solution $\left(5.0 \mathrm{mg} \mathrm{mL}^{-1}\right)$ was added for incubating another $4 \mathrm{~h}$ and following the medium was removed. $200 \mathrm{~mL}$ of DMSO was used to dissolve the purple formazan crystals and the absorbance was monitored with a microplate reader at 490 nm. A linear relationship between cell number and optical density was established, based on which the cell viability ratio was calculated.

To observe the receptor HeLa cell intake of nanocomposites, cells was sowed in 
confocal cell dishes for $12 \mathrm{~h}$. Then the medium was removed and $1 \mathrm{~mL}$ of $\mathrm{hCu}_{2-\mathrm{x}} \mathrm{S} @ \mathrm{Au}-\mathrm{DOX}-\mathrm{TDA}\left(100 \mu \mathrm{g} \mathrm{mL} \mathrm{m}^{-1}\right)$ was added for co-incubating with different times $(2,4,6$ h). Afterwards, HeLa cells were washed three times with PBS, fixed with $4 \%$ paraformaldehyde for $15 \mathrm{~min}$ and $500 \mu \mathrm{L}$ DAPI staining for $8 \mathrm{~min}$. Finally, the imaging was acquired by confocal laser scanning microscopy. Cellular intake of free DOX under the same conditions was as control.

1.9 Animal Experiments. BALB/c nude mice ((aged 4 weeks, weight 12-16 g, female) were obtained from Beijing SPF Biotechnology Co., Ltd. $6 \times 10^{6}$ HeLa cells were subcutaneously injected into the right flank of each athymic BALB/c nude mice to establish the tumor model. The mice were randomly divided to control group and therapy group as tumors grew to about $80 \mathrm{~mm}^{3}$. Mice were treated with $50 \mu \mathrm{L}$ vehicle by intratumor injection every two days for 8 times. Tumor size was recorded every two days and calculated by using the equation (4):

$$
\text { Tumor size }\left(\mathrm{mm}^{3}\right)=0.5 \times \text { length } \times \text { width }^{2}
$$




\section{SUPPORTING FIGURES}
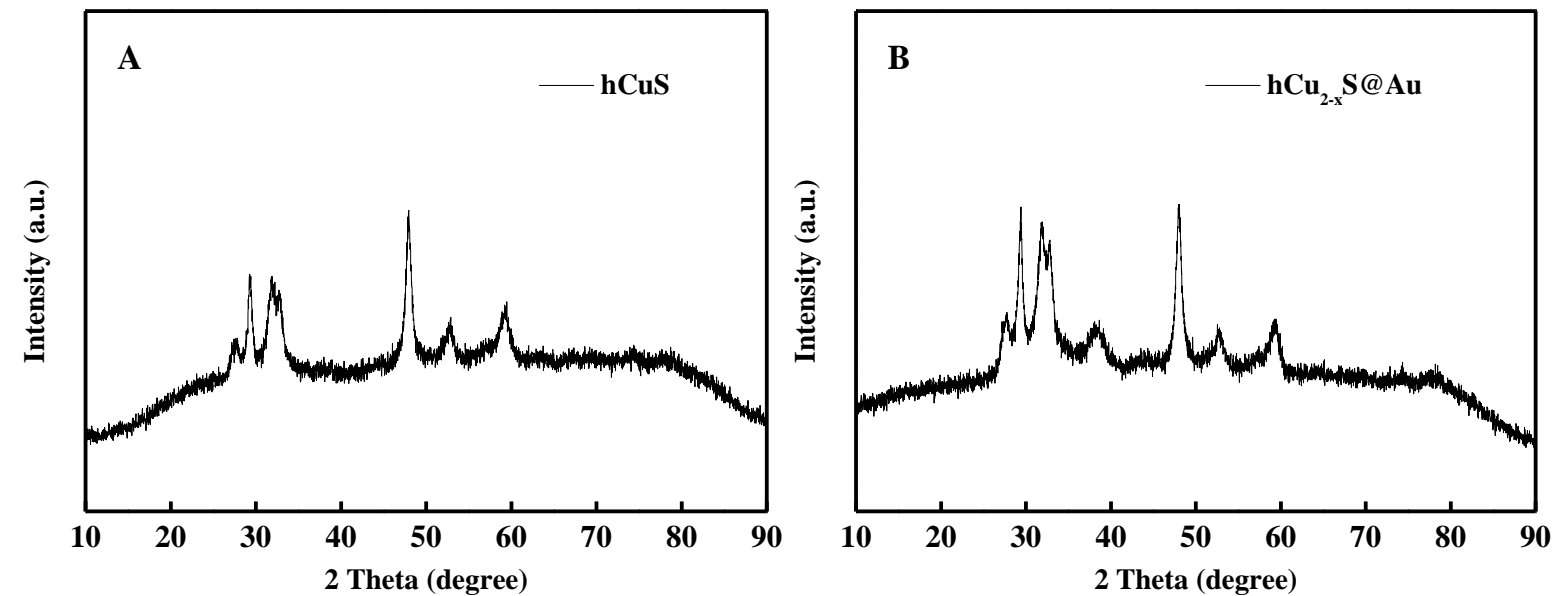

Figure S1. XRD patterns of hCuS (A) and $\mathrm{hCu}_{2-\mathrm{x}} \mathrm{S} @ \mathrm{Au}$ nanoparticles (B). 


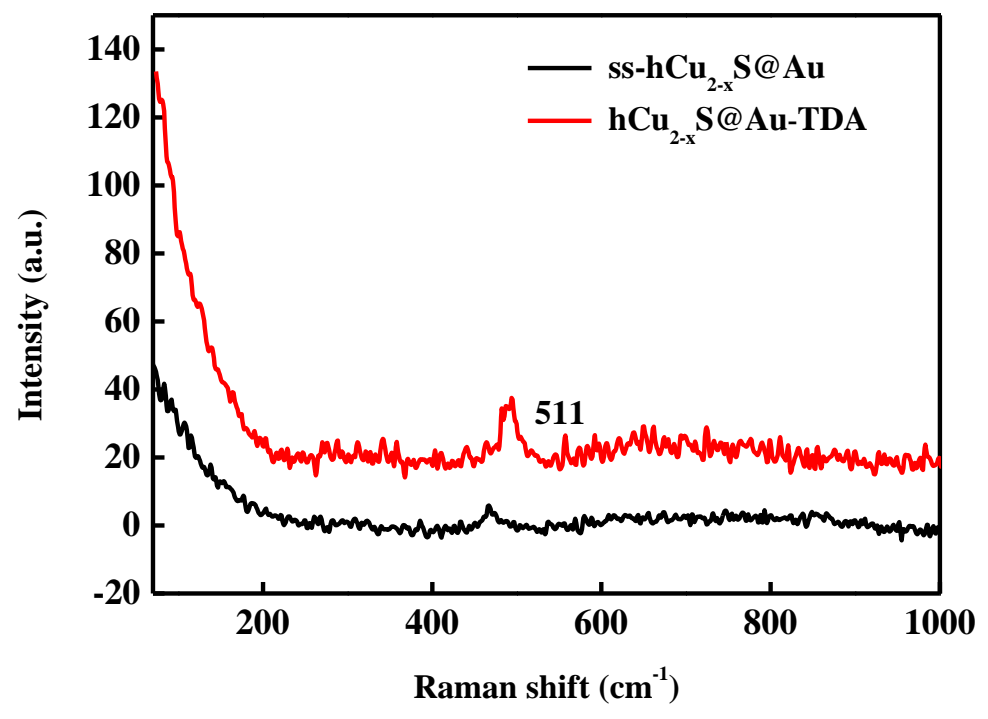

Figure S2. Raman spectra of ss-hCu $\mathrm{u}_{2-\mathrm{x}} \mathrm{S} @ \mathrm{Au}$ (black line) and hCu $\mathrm{u}_{2-\mathrm{x}} \mathrm{S} @ \mathrm{Au}-\mathrm{TDA}$ nanoparticles. Peak assignment is appeared at $511 \mathrm{~nm}$. 

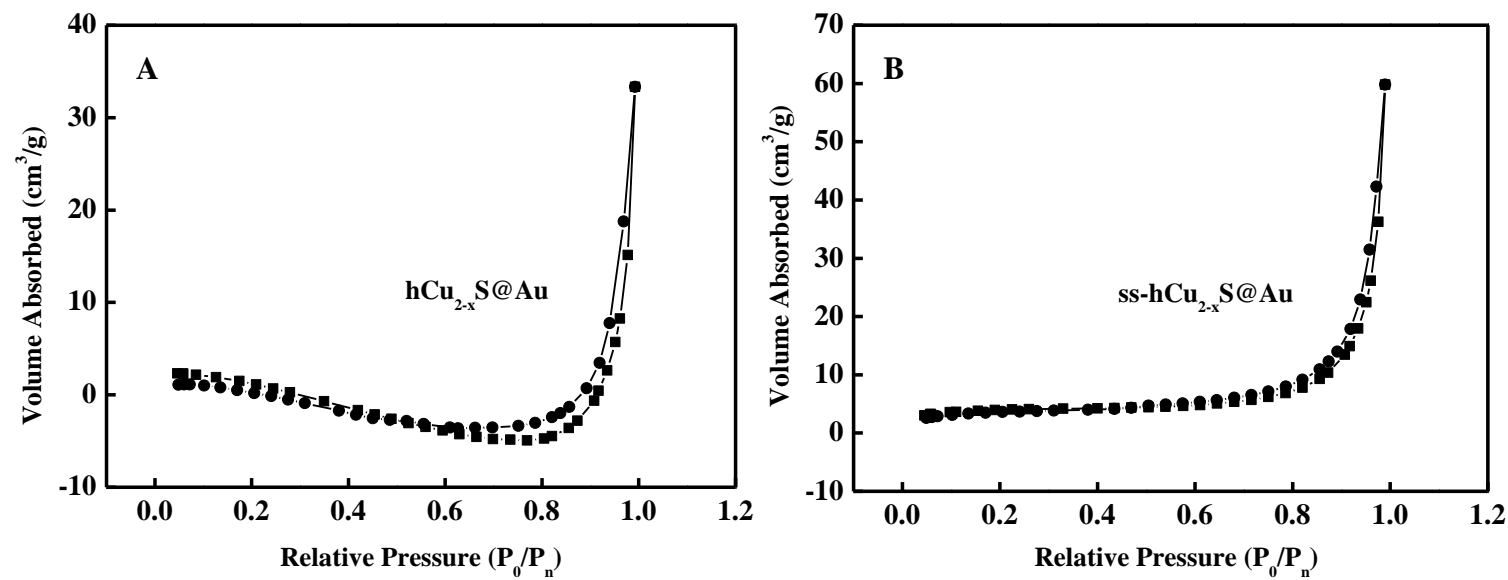

Figure S3. $\mathrm{N}_{2}$ absorption/desorption isotherms of $\mathrm{hCu}_{2-\mathrm{x}} \mathrm{S} @ \mathrm{Au}(\mathrm{A}), \mathrm{ss}-\mathrm{hCu}_{2-\mathrm{x}} \mathrm{S} @ \mathrm{Au}$ nanoparticles (B). 

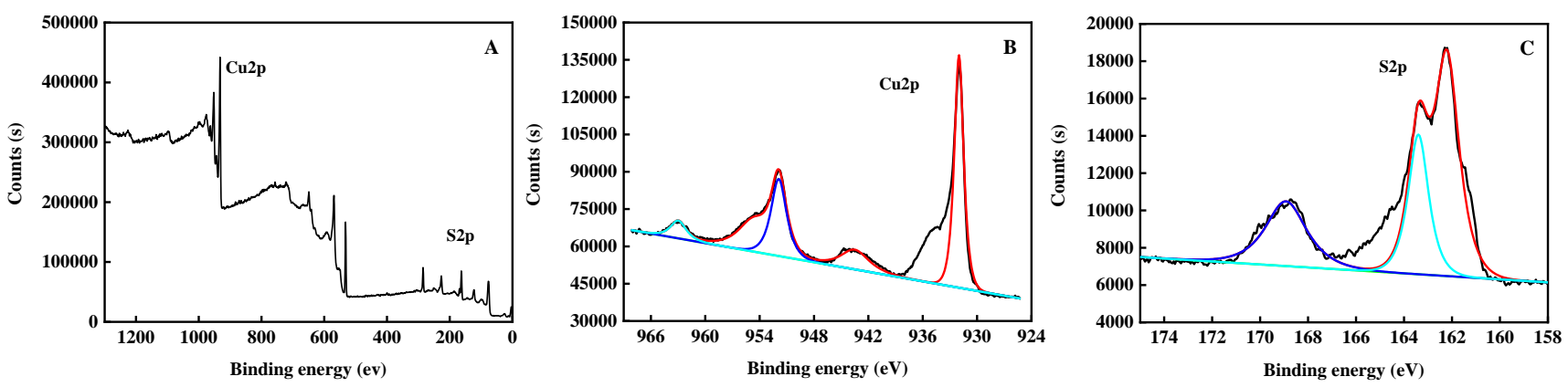

Figure S4. XPS survey spectrum of hCuS nanoparticles (A), and high resolution $\mathrm{Cu}$ 2p (B) and S 2p (C) spectra of hCuS. 

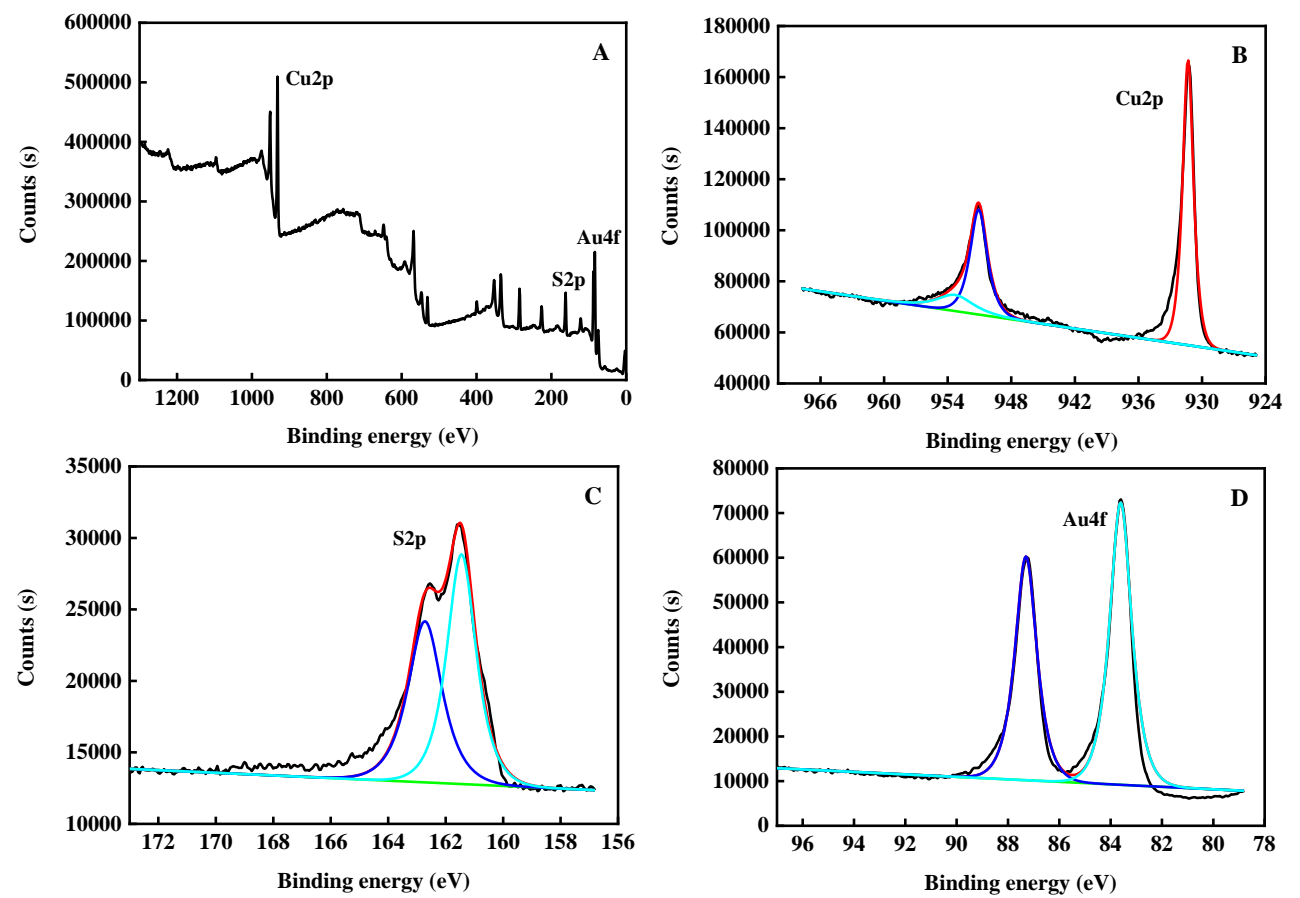

Figure S5. XPS survey spectrum of the $\mathrm{hCu}_{2-\mathrm{x}} \mathrm{S} @ \mathrm{Au}$ nanoparticles $(\mathrm{A})$ and high resolution $\mathrm{Cu} 2 \mathrm{p}(\mathrm{B}), \mathrm{S} 2 \mathrm{p}(\mathrm{C})$ and $\mathrm{Au} 4 \mathrm{f}$ (D) spectra of $\mathrm{hCu}_{2-\mathrm{x}} \mathrm{S} @ \mathrm{Au}$. 

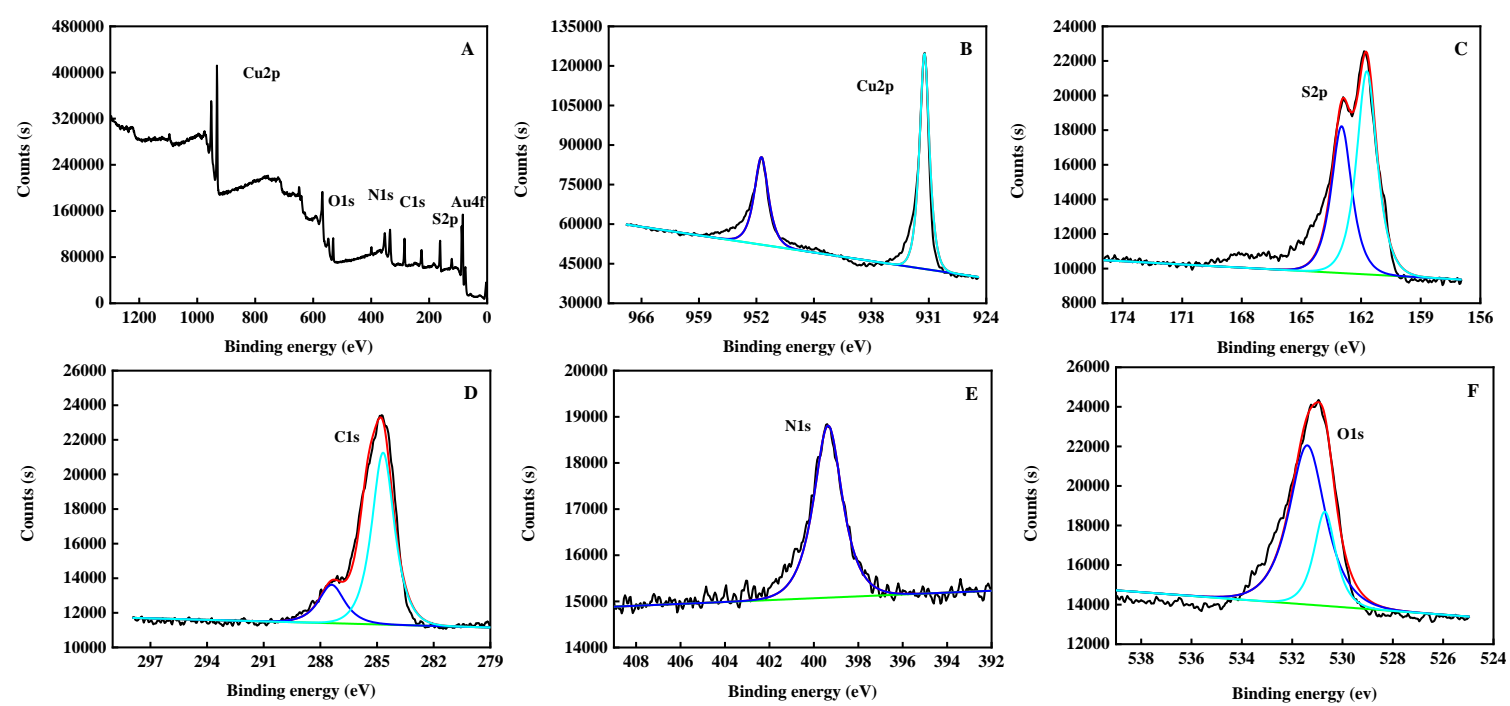

Figure S6. XPS survey spectrum of the ss-hCu $\mathrm{Cu}_{2-\mathrm{x}} \mathrm{S} @ \mathrm{Au}$ nanoparticles (A) and high resolution $\mathrm{Cu} 2 \mathrm{p}(\mathrm{B}), \mathrm{S} 2 \mathrm{p}(\mathrm{C}), \mathrm{C}$ 1s (D), $\mathrm{N}$ 1s (E) and $\mathrm{O}$ 1s (F) spectra of ss-hCu2-x $\mathrm{S} @ \mathrm{Au}$. 


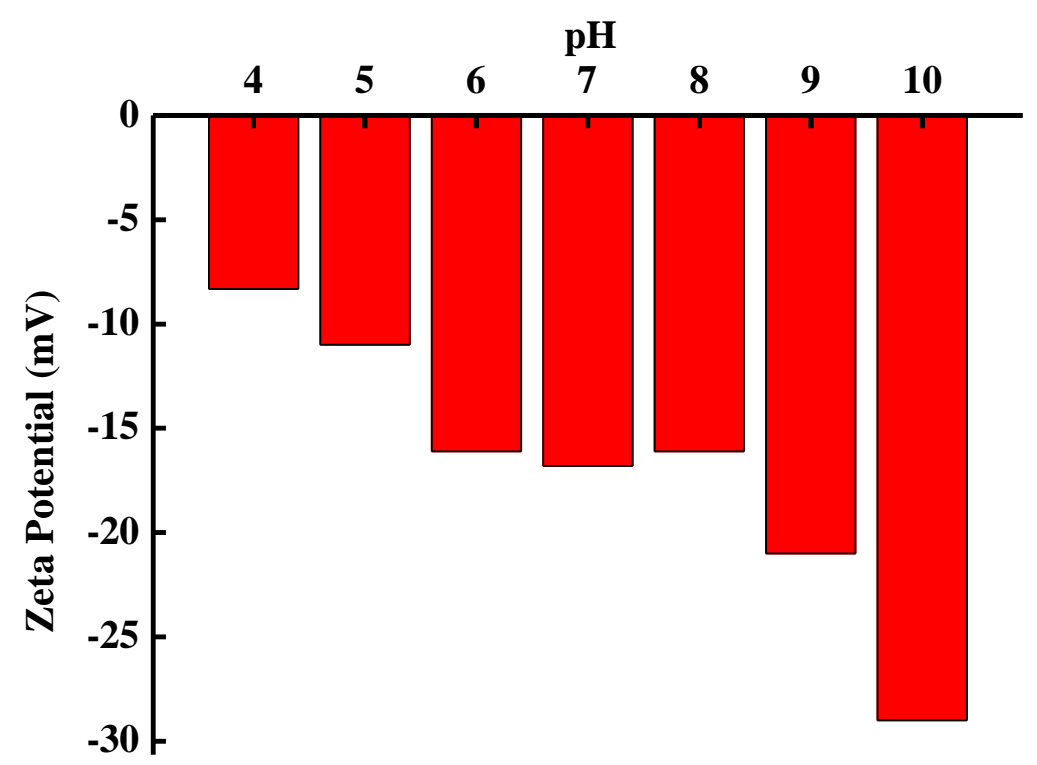

Figure S7. Zeta potential of ss-hCu $\mathrm{Cu}_{2-\mathrm{x}} \mathrm{S} @ \mathrm{Au}$ particles. 


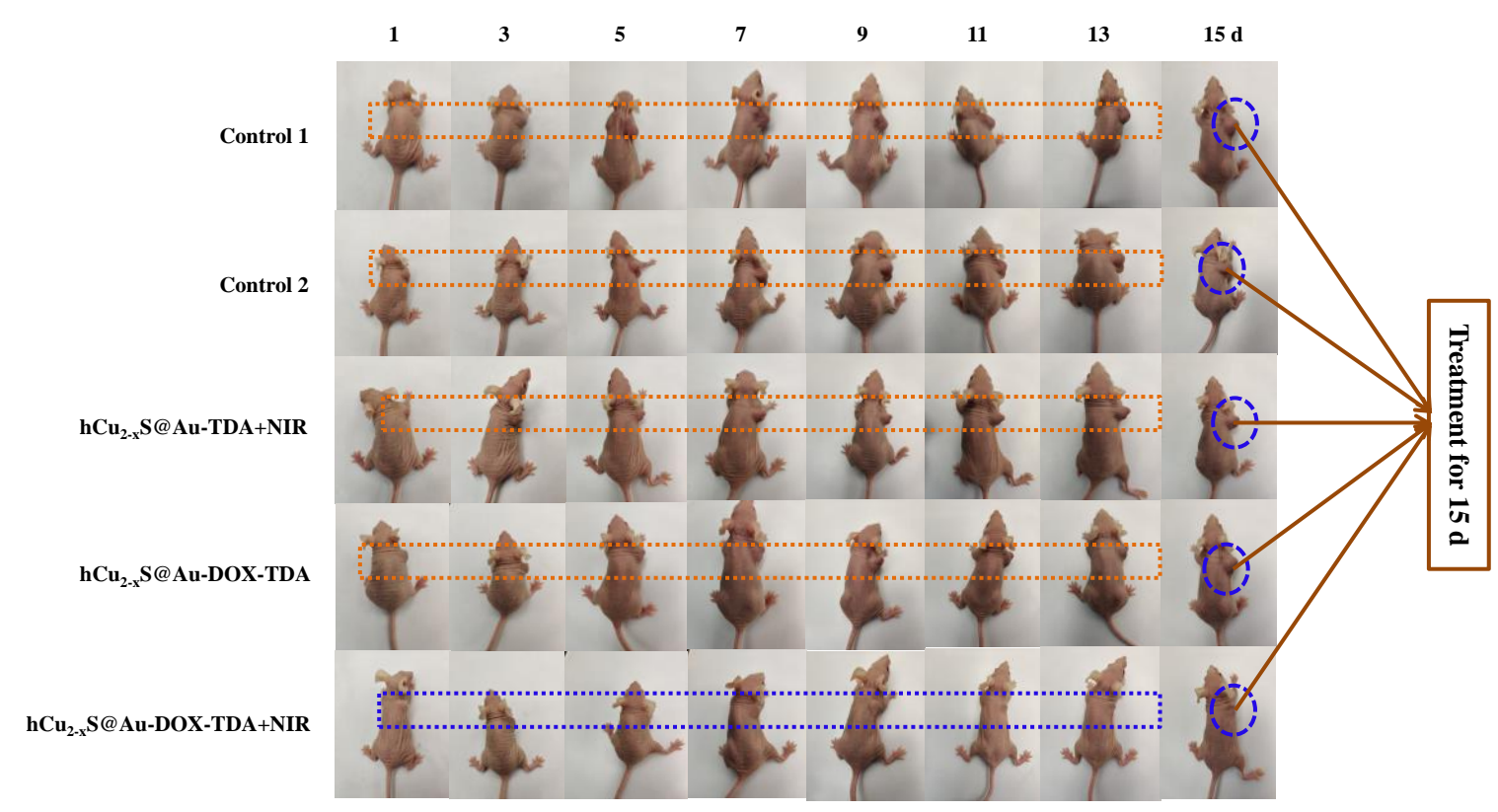

Figure S8. Therapeutic photos of tumor-bearing mice after various agents' injection during 15 days. 


\section{Reference}

(1) Wu, H. X.; Shi, H. L.; Wang, Y. P.; Jia, X. Q.; Tang, C. Z.; Zhang, J. M.; Yang, S. P. Hyaluronic Acid Conjugated Graphene Oxide for Targeted Drug Delivery. Carbon 2014, 69, 379-389.

(2) Tian, Q. W.; Hu, J. Q.; Zhu, Y. H.; Zou, R. J.; Chen, Z. G.; Yang, S. P.; Li, R. W.; Su, Q. Q.; Han, Y.; Liu, X. G. Sub-10 nm Fe $\mathrm{O}_{4} @ \mathrm{Cu}_{2-\mathrm{x}} \mathrm{S}$ Core-Shell Nanoparticles for Dual-Modal Imaging and Photothermal Therapy. J. Am. Chem. Soc. 2013, 135, 8571-8577.

(3) Roper, D. K.; Ahn, W.; Hoepfner, M. Microscale Heat Transfer Transduced by Surface Plasmon Resonant Gold Nanoparticles. J. Phys. Chem. C 2007, 111, 3636-3641.

This information is available free of charge via the Internet at http://pubs.acs.org/ 